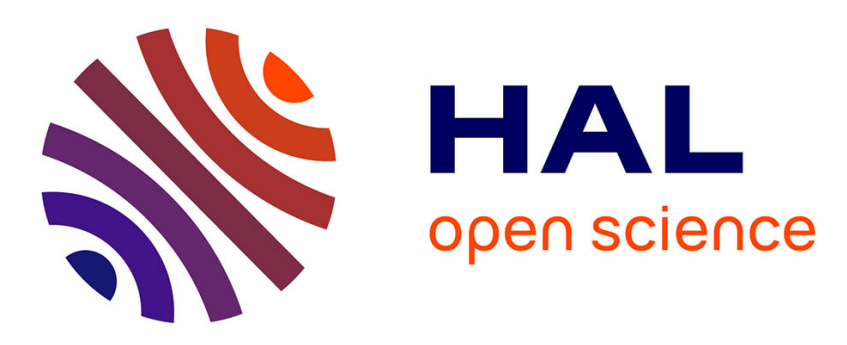

\title{
Verb morphology and conjugation classes in Dunan (Yonaguni)
}

Thomas Pellard, Masahiro Yamada

\section{To cite this version:}

Thomas Pellard, Masahiro Yamada. Verb morphology and conjugation classes in Dunan (Yonaguni). Kiefer, Ferenc; Blevins, James P.; Bartos, Huba. Perspectives on morphological organization: Data and analyses, Brill, pp.31-49, 2017, 9789004342910. 10.1163/9789004342934_004 . hal-01493096

\section{HAL Id: hal-01493096 \\ https://hal.science/hal-01493096}

Submitted on 20 Mar 2017

HAL is a multi-disciplinary open access archive for the deposit and dissemination of scientific research documents, whether they are published or not. The documents may come from teaching and research institutions in France or abroad, or from public or private research centers.
L'archive ouverte pluridisciplinaire HAL, est destinée au dépôt et à la diffusion de documents scientifiques de niveau recherche, publiés ou non, émanant des établissements d'enseignement et de recherche français ou étrangers, des laboratoires publics ou privés.

\section{(c)(1)}

Distributed under a Creative Commons Attribution| 4.0 International License 
CHAPTER 2

\title{
Verb morphology and conjugation classes in Dunan (Yonaguni)
}

\author{
Thomas Pellard and Masahiro Yamada
}

\section{Dunan and the other Japonic languages}

\subsection{Japanese and the other Japonic languages}

Most Japonic languages have a relatively simple and transparent morphology. ${ }^{1}$ Their verb morphology is usually characterized by a highly agglutinative structure that exhibits little morphophonology, with only a few conjugation classes and a handful of irregular verbs. For instance, Modern Standard Japanese has only two regular conjugation classes: a consonant-stem class (C) and a vowelstem class $(\mathrm{V})$. These two classes are further cross-classified by the accented vs. unaccented prosodic criterion (Table 2.1), but most of the allomorphy can easily be accounted for by phonotactic constraints: when two consonants or two vowels would cluster, deletion occurs $\left({ }^{*} \mathrm{C}_{i} \mathrm{C}_{j} \rightarrow \mathrm{C}_{i},{ }^{*} \mathrm{~V}_{i} \mathrm{~V}_{j} \rightarrow \mathrm{V}_{i}\right)$.

TABLE 2.1: Verb conjugation classes in Modern Standard Japanese

\begin{tabular}{llllll}
\hline & \multicolumn{2}{c}{$\mathrm{C}$} & & \multicolumn{2}{c}{$\mathrm{V}$} \\
\cline { 2 - 3 } \cline { 5 - 6 } & $\begin{array}{l}\text { unaccented } \\
\text { 'work' }\end{array}$ & $\begin{array}{l}\text { accented } \\
\text { 'swim' }\end{array}$ & & $\begin{array}{l}\text { unaccented } \\
\text { 'align' }\end{array}$ & $\begin{array}{l}\text { accented } \\
\text { 'get up' }\end{array}$ \\
\hline PRESENT & hatarak-u & oyóg-u & & narabe-ru & okí-ru \\
NEGATIVE & hatarak-anai & oyog-ánai & & narabe-nai & okí-nai \\
CONDITIONAL & hatarak-éba & oyóg-eba & & narabe-réba & okí-reba \\
HORTATIVE & hatarak-óo & oyog-óo & & narabe-yóo & oki-yóo \\
IMPERATIVE & hatarak-é & oyóg-e & & narabe-ró & okí-ro \\
MEDIAL & hatarai-te & oyói-de & & narabe-te & óki-te \\
\hline
\end{tabular}

1 See for example the descriptions in Shibatani 1990, Shimoji \& Pellard 2010, Heinrich et al. 2015 . 
Japanese is close to being a canonical agglutinative language, which explains why virtually all studies on Japanese verb morphology have adopted one of the various frameworks of morpheme-based morphophonology, like structuralist morphophonemics (Bloch 1946, Martin 1952), classical generative phonology (McCawley 1968), or optimality theory (Ito \& Mester 2004). Though studies on other Japonic languages often follow the same vein, ${ }^{2}$ the case of the Dunan (Yonaguni) language cannot easily be treated in the same way.

\subsection{Dunan (Yonaguni)}

Dunan (Iso 639-3 yoi), also called Yonaguni, ${ }^{3}$ is a highly endangered Japonic language of the Southern Ryukyuan branch, spoken by approximately 400 speakers located on Yonaguni Island (Okinawa prefecture, Japan). In sharp contrast with its relatives, Dunan exhibits a unusually complex verb morphology for a Japonic language, mostly due to some drastic historical changes. The verb morphology of Dunan seems be the most complex one within the whole Japonic family, and a systematic description challenges in several interesting ways morpheme-based approaches.

The present work is based on original data gathered by the authors during fieldwork on Yonaguni Island between 2010 and 2014. The analysis relies on a morphological database containing more than 500 verbs obtained through either elicitation or analysis of oral text recordings. In order to test our understanding and analysis of Dunan verb morphology, we fully formalized our description and implemented it as a finite state transducer with the XFST software (Beesley \& Karttunen 2003). The transducer obtained can be used for both generation and recognition. As a generator, it generates the complete paradigm of any verb, i.e. the set of all its possible inflectional forms together with their morphosyntactic labels. When used as a morphological analyzer, the transducer can output all morphosyntactic possible analyses of an unlabeled inflected form, i.e. its morphosyntactic features and the identity and conjugation-class membership of the underlying verbal lexeme. Preliminary

2 E.g. Ashworth 1973 on Shuri Okinawan, Lawrence (1990) on Nakijin Okinawan, or Arimoto (2001) on Dunan.

3 See Yamada et al. 2013, 2015 for a more detailed grammatical overview. The practical orthography adopted in this study uses the following conventions: $C h=\left[\mathrm{C}^{\mathrm{h}}\right] ; C C=\left[\mathrm{C}^{\text {? }}\right]$; $y=[\mathrm{j}] ; r=[\mathrm{r}] ; c=[\mathrm{ts}] ; c \rightarrow\left[\mathrm{t}_{6}\right], s \rightarrow[\mathrm{c}], h \rightarrow[\mathrm{c}] / \longrightarrow\{i, y\} ; h \rightarrow[\phi] \sim[\mathrm{M}] /$ $\{u, w\} ; n=$ homorganic $/ \_\mathrm{C},[\mathrm{\eta}] / \ldots$ _ $\mathrm{X}=$ any string including zero. Tone categories are indicated by an accent on the first vowel of a word $\left(^{\prime}=\right.$ High tone, ' = Low tone, ${ }^{\wedge}=$ Falling tone). 
tests run on a small corpus of transcribed texts and elicited data revealed no error in our analysis.

The following presents an outline of the verb morphology of Dunan, limited to the basic synthetic forms of regular verbs. Focus is put on the partition of verbs into classes and its morphomic pattern. Three morphomic factors are identified as partitioning verbs into conjugation classes: stem alternation, suffix allomorphy, and metatony. The resulting system of paradigm classes is found to be opaque and to show little interpredictability between paradigm cells, i.e. few reliable inferences can be made from one inflected form about other forms. Morpheme-based approaches are not well-suited for the analysis of Dunan's verb morphology, which rather calls for an abstractive Word and Paradigm approach.

\section{$2 \quad$ Verb morphology in Dunan: Overview}

\subsection{Verb template}

The full morphological template of Dunan synthetic verb forms is illustrated in Table 2.2. We will focus in the following on the basic forms of regular verbs only and on the combination between a root and the first suffix since it is the main locus of complexity.

TABLE 2.2: Verb template of Dunan

\begin{tabular}{|c|c|c|c|c|c|}
\hline $\mathrm{O}$ & 1 & 2 & 3 & 4 & 5 \\
\hline \multirow{8}{*}{ Root } & \multirow{8}{*}{$\begin{array}{c}\text { CAUSATIVE } \\
\varnothing\end{array}$} & \multirow{8}{*}{$\begin{array}{c}\text { PASSIVE } \\
\varnothing\end{array}$} & & PRESENT & INDICATIVE \\
\hline & & & $\varnothing$ & PAST & PARTICIPLE \\
\hline & & & NEGATIVE & PAST & CIRCUMSTANTIAL \\
\hline & & & PERFECT & $\varnothing$ & CONDITIONAL \\
\hline & & & \multirow{4}{*}{$\varnothing$} & \multirow{4}{*}{$\varnothing$} & IMPERATIVE \\
\hline & & & & & PROHIBITIVE \\
\hline & & & & & HORTATIVE \\
\hline & & & & & MEDIAL \\
\hline
\end{tabular}




\subsection{Conjugation classes}

In Dunan, not all verbs exhibit the same morphological patterning in inflection, and verbs can thus be partitioned into several conjugation classes. These classes are not predictable from the phonological properties of verb roots, though there is indeed a correlation between conjugation classes and the segmental shape of roots. That correlation has been largely obscured by drastic historical changes, like the merger of high and mid vowels $\left({ }^{*} e>i,{ }^{*} o>u\right.$ ), vowel syncope in several environments, palatalization and subsequent deaffrication of velars before ${ }^{*} i$ (e.g. ${ }^{*} k>t / \ldots i$ ), or the univerbation of stems with a stative auxiliary. Compare for instance the alternations within the partial paradigms of the verbs 'blow' and 'fish' (<*'feed') in Dunan with the relative simplicity of their Modern Japanese cognates presented in Table 2.3.

TABLE 2.3: Comparison between Dunan and Japanese verbs

\begin{tabular}{lllll}
\hline & \multicolumn{2}{c}{ 'blow' } & \multicolumn{2}{c}{ 'fish', 'feed' } \\
& Dunan & Japanese & Dunan & Japanese \\
\hline \multirow{2}{*}{ PRESENT } & kkùn & fúku & ppàn & kuwásu \\
PAST & ttìtan & fúita & ppàtan & kuwáshita \\
IMPERATIVE & $k k i$ & fúke & ppài & kuwáse \\
MEDIAL & $t t \hat{\imath}$ & fúki & ppâsi & kuwáshi \\
\hline
\end{tabular}

As will be argued below, the conjugation classes of Dunan are not predictable from syntactico-semantic properties either. Identifying the class membership of a verb and its conjugation pattern is thus not straightforward and requires knowledge of several inflected forms.

The exact number of classes required in order to account for all patterns depends on the number and the degree of abstractness of the morphophonological rules one is ready to allow. In any case, conjugation classes are the product of the interaction of three independent factors: stem allomorphy, suffix allomorphy, and tone alternation (metatony).

Whereas canonical inflectional classes are based on different sets of affixes (Corbett 2009), in Dunan, classes are primarily based on patterns of stem 
alternation rather than suffix allomorphy. Such alternations cannot be reduced to an epiphenomenon due to phonological readjustment rules, but they must be specified within the morphology. The exact number and analysis of these alternations depends on the segmentation procedure adopted, but the following account tries to maximize consistency and to keep balance between stem allomorphy and suffix allomorphy.

\subsection{Phonology of stem alternations}

Any regular verb exhibits up to three segmentally distinct stem forms in Dunan. ${ }^{4}$ Such stems often exhibit a reduction/augmentation pattern, and it is generally difficult if not impossible to posit a single underlying base (Table 2.4).

TABLE 2.4: Phonology of stem alternations

\begin{tabular}{lllllllll}
\hline 'see' & 'tear' & 'raise' & 'rest' & 'teach' & 'dry' & 'become' & 'make' & 'slip' \\
\hline nn. & sag. & kkan. & dug. & nar. & hw. & n. & kkw. & ngur. \\
& sat. & kkana. & dugw. & nara. & hu. & na. & kku. & ngur. \\
& & & dugu. & naras. & hus. & nar. & kkur. & ngurir. \\
\hline
\end{tabular}

For instance, velar-stem verbs like sag. 'tear' in Table 2.4 exhibit an alternation between a velar and a dental consonant: $\mathrm{X} k \cdot \leftrightarrow \mathrm{X} t \cdot \mathrm{X} g \cdot \leftrightarrow \mathrm{X} t, \mathrm{X} \eta \cdot \leftrightarrow \mathrm{X} d$. (Table 2.5). This alternation cannot be accounted for by a simple phonological rule of the type [DORSAL] $\rightarrow$ [CORONAL] / - [CORONAL], where the coronal context stands for either $i$ or $y$. Even though a dental stem appears in front of the medial verb suffix $-i$, e.g. sat-i, it fails to appear before the imperative $(-i)$ and conditional $(-y a)$ suffixes, e.g. sag-i, sag-ya (Table 2.5).

4 See section 5 for suprasegmental alternations. Here stems are followed by a raised dot $(\cdot)$ to indicate they are bound forms requiring a suffix, and not a hyphen (-) in order to clearly distinguish them from affixes. 
TABLE 2.5: Alternation between velars and dentals in verb stems

\begin{tabular}{|c|c|c|c|}
\hline & $\begin{array}{c}k \\
\mathrm{X}=\operatorname{sun} \text { 'pull' }\end{array}$ & $\begin{array}{c}g \\
\mathrm{X}=s a^{\text {'bloom' }}\end{array}$ & $\begin{array}{c}\eta \\
\mathrm{X}=h a \text { 'deal' }\end{array}$ \\
\hline CONDITIONAL & $\mathrm{Xkya}$ & $\mathrm{Xgya}$ & Хрууа \\
\hline IMPERATIVE & $\mathrm{X} k i$ & $\mathrm{Xgi}$ & $\mathrm{X} \eta i$ \\
\hline PAST & Xtitan & Xtitan & Xditan \\
\hline MEDIAL & $\mathrm{X} t i$ & $\mathrm{X} t i$ & $\mathrm{Xdi}$ \\
\hline PERFECT & Xtyan & Xtun & Xdyan \\
\hline
\end{tabular}

The alternation between velars and dentals is thus not phonologically motivated and is not triggered by an automatic mechanism ensuring well-formedness conditions. It is the result of a diachronic phonological change which has been morphologized, i.e. it results from the palatalization and deaffrication of velars before ${ }^{*} i$ and the following raising of mid vowels $\left({ }^{*} e>i\right)$.

Morphologically conditioned alternations are also found elsewhere (Table 2.6), like for example in sigmatic verbs, ${ }^{5}$ whose imperative is of the form X-i, in contrast with their Xs-i medial form. Both the imperative and the medial are marked by a suffix $-i$, but a different stem is used in each case. Similarly, for $i$-rhotic ${ }^{6}$ verbs, the imperative (Xir-i) differs from the medial (X-i), and the conditional (Xir-ya) from the perfect (X-ya-), but they are differentiated by the shape of the stem rather than by that of the suffix.

TABLE 2.6: Morphologically conditioned alternations

\begin{tabular}{lll}
\hline & $\mathrm{X}=k h$ 'do' & $\mathrm{X}=$ ngara 'wet' \\
\hline IMPERATIVE & $\mathrm{X} i r i$ & $\mathrm{X} i$ \\
MEDIAL & $\mathrm{X} i$ & $\mathrm{X} s i$ \\
CONDITIONAL & $\mathrm{X} i r y a$ & - \\
PERFECT & Xyan & Xsyan \\
\hline
\end{tabular}

5 Those verbs that exhibit a $s \sim \varnothing$ alternation.

6 Those verbs that exhibit a $r \sim \varnothing$ alternation and have a vowel $i$ before the $r$. 


\subsection{Patterns of stem alternation}

As stated above, the number of distinct stem forms per verb does not exceed three. However, the distribution of stems within paradigms is not uniform for all verbs (Table 2.7). For instance, in the case of verbs with three stems, the shortest stem usually appears only in the perfect cell, but not in the case of sigmatic verbs, where the same stem is shared by the hortative, medial, and perfect cells. On the other hand, for sigmatic verbs, the shortest stem is used in the negative cell only, while for most other classes the negative shares the same stem as the present and imperative forms.

The number of stems needed to account for the whole pattern of stem alternations across the different classes amounts to seven, i.e. more than twice the number of distinct stem forms for any verb (Table 2.7). This leads to the unexpected conclusion that there are almost as many stems as basic forms.

TABLE 2.7: Patterns of stem alternation and their relative type frequency

\begin{tabular}{|c|c|c|c|c|c|c|c|c|c|c|c|c|}
\hline & & $\begin{array}{l}\mathrm{X}=\text { that } \\
\text { 'stand' }\end{array}$ & $\begin{array}{l}\mathrm{X}=\text { sun } \\
\text { 'pull' }\end{array}$ & $\begin{array}{l}\mathrm{X}=n g \\
\text { 'get wet' }\end{array}$ & $\begin{array}{l}\mathrm{X}=\text { hud } \\
\text { 'grow' }\end{array}$ & $\begin{array}{l}\mathrm{X}=k k \\
\text { 'make' }\end{array}$ & $\begin{array}{l}\mathrm{X}=k h \\
\text { 'do' }\end{array}$ & $\begin{array}{l}\mathrm{X}=h \\
\text { 'eat' }\end{array}$ & $\begin{array}{l}\mathrm{X}=d u g \\
\text { 'rest' }\end{array}$ & $\begin{array}{l}\mathrm{X}=\operatorname{mag} \\
\text { 'cook' }\end{array}$ & $\begin{array}{l}\mathrm{X}=u t \\
\text { 'drop' }\end{array}$ & $\begin{array}{l}\mathrm{X}=h \\
\text { 'dry' }\end{array}$ \\
\hline 1 & NEG & $\mathrm{X}$ & $\mathrm{X} k$ & $\mathrm{X} a r$ & Xur & Xur & Xir & $X$ & $X$ & X & $X$ & $\mathrm{X} w$ \\
\hline \multirow{2}{*}{2} & PRES & $\mathrm{X}$ & $\mathrm{X} k$ & Xar & Xur & Xur & Xir & $\mathrm{X}$ & $\mathrm{X}$ & $\mathrm{X} a$ & $\mathrm{Xu}$ & $\mathrm{Xu}$ \\
\hline & COND & $\mathrm{X}$ & $\mathrm{X} k$ & Xar & Xur & Xur & Xir & - & - & - & - & - \\
\hline \multirow{2}{*}{3} & IMP & $\mathrm{X}$ & $\mathrm{X} k$ & $\mathrm{Xar}$ & Xur & Xur & Xir & $\mathrm{Xa}$ & $\mathrm{Xu}$ & $\mathrm{X} a$ & $\mathrm{Xu}$ & $\mathrm{Xu}$ \\
\hline & CIRC & $X$ & $\mathrm{X} k$ & Xar & Xur & Xur & Xir & $\mathrm{X} a$ & $\mathrm{Xu}$ & $\mathrm{X} a$ & $\mathrm{Xu}$ & $\mathrm{Xu}$ \\
\hline 4 & PROH & $\mathrm{X}$ & $\mathrm{X} k$ & $\mathrm{X} a$ & $\mathrm{Xu}$ & $\mathrm{Xu}$ & $\mathrm{X} i$ & $X$ & $\mathrm{X}$ & $\mathrm{X} a$ & $\mathrm{Xu}$ & $\mathrm{Xu}$ \\
\hline 5 & PAST & $X$ & $\mathrm{X} t$ & $\mathrm{X} a$ & $\mathrm{Xu}$ & $\mathrm{Xu}$ & $\mathrm{X} i$ & $\mathrm{X} a$ & $\mathrm{Xu}$ & $\mathrm{X} a$ & $\mathrm{Xu}$ & $\mathrm{Xu}$ \\
\hline \multirow{2}{*}{6} & HORT & $X$ & $\mathrm{X} t$ & $\mathrm{X} a$ & $\mathrm{Xu}$ & $\mathrm{Xu}$ & $\mathrm{X} i$ & $\mathrm{X} a$ & $\mathrm{Xu}$ & Xas & Xus & Xus \\
\hline & MED & $\mathrm{X}$ & $\mathrm{X} t$ & $\mathrm{X} a$ & $\mathrm{Xu}$ & $\mathrm{Xu}$ & $\mathrm{X} i$ & $\mathrm{X} a$ & $\mathrm{Xu}$ & Xas & $\mathrm{Xus}$ & Xus \\
\hline \multirow{2}{*}{7} & PERF & X & $\mathrm{X} t$ & $\mathrm{X}$ & X & $\mathrm{X} w$ & $X$ & X & $\mathrm{X} w$ & Xas & $\mathrm{Xus}$ & Xus \\
\hline & Freq. & $10.60 \%$ & $12.4 \%$ & $14.44 \%$ & $1.13 \%$ & $5.64 \%$ & $33.62 \%$ & $2.71 \%$ & $1.58 \%$ & $14.67 \%$ & $2.71 \%$ & $0.45 \%$ \\
\hline
\end{tabular}

\subsection{Status of verb stems}

As illustrated above, the pattern of stem alternations of a verb depends on its conjugation class. Verbs from different classes can thus share one phonologically similar stem, while having completely different other stems (Table 2.4, 2.7). The distribution of stems within a paradigm is also class-specific. Obviously, it does not depend on phonological properties, but it is not regulated by 
morphosyntactic features either. Depending on the verb class, stems will partition the paradigm cells in different sets, like \{negative, present, prohibitive\}, \{imperative, circumstantial, past, hortative, medial\}, \{perfect $\}$ for vocalic verbs, ${ }^{7}$ but \{negative\}, \{present, imperative, circumstantial, prohibitive, past\}, \{hortative, medial, perfect $\}$ for sigmatic verbs. Such partitions are unmotivated since forms in the same set do not necessarily share common morphosyntactic features. It is even true for the imperative and the circumstantial, for which the same stem is used for all verbs while the two have little in common from a grammatical point of view.

The distribution of stems is purely morphological, and stems themselves underlie sets of forms that do not realize any coherent set of morphosyntactic features. The unavoidable conclusion is that in Dunan, stems are meaningless and are thus purely morphological objects, i.e. they are morphomic (Aronoff 1994).

\section{Suffix allomorphy}

\subsection{Overview}

Suffix allomorphy is much less developed than stem allomorphy in Dunan verb morphology. A few cases of truncation of identical vowel sequences $\left(\mathrm{V}_{i}-\mathrm{V}_{i} \rightarrow\right.$ $\mathrm{V}_{i}$ ) are found, like in the case of the medial form of $i$-rhotic verbs, where only one $i$ surfaces from the concatenation of an $i$-ending stem with the suffix $-i$, but these are rather trivial.

Allomorphy is found in the perfect $(\{y a, a, y u, u\})$, circumstantial $(\{u b a$, $i b a, b a\})$, prohibitive $(\{u n n a, n n a\})$, past $(\{i t a, t a\})$, and present $(\{u, \varnothing\})$ suffixes. The choice of the allomorph can be shown to be independent of both phonological and morphosyntactic properties and to depend on purely morphological features.

\subsection{Conditioning}

Like stem alternation, suffix allomorphy is not phonologically conditioned in Dunan, despite what things look like at first sight. For instance, the choice between the two allomorphs $-u b a$ and -iba of the circumstantial suffix seems at first sight to be amenable to a phonological treatment, since they are in complementary distribution. The allomorph $-u b a$ is found after consonantending stems only, while -iba appears after vowel-ending stems only. This would however overlook the important fact that the choice of the stem appearing before the suffix is idiosyncratic and cannot be accounted for by the phonology.

7 Those verbs that exhibit a vowel $\sim \varnothing$ alternation. 
For $u$-rhotic verbs, a consonant-ending stem is used (Xur-uba), even though a vowel stem is available $(\{\mathrm{X} u, \mathrm{Xur}, \mathrm{X} w \cdot\})$, while for $u$-sigmatic verbs a vowelending stem $(\mathrm{X} u-i b a)$ is found, and not one of their consonant-ending stem $\left(\left\{\mathrm{Xu} \cdot \mathrm{X} u s \cdot \mathrm{X}_{\mathrm{C}} \cdot\right\}\right)$. Moreover, there is yet another allomorph $-b a$ used in combination with the past suffix (X-ta-ba). The same is true for other cases of suffix allomorphy, and there is thus an arbitrary co-indexing of stems and suffixes.

The case of the perfect suffix is even more telling, since otherwise homophonous verbs take different suffix allomorphs. For example, verbs such as nirun 'boil' and nirun 'get boiled', or sagun 'tear' and sagun 'bloom', have identical paradigms except for their perfect form, respectively nyan vs. nyun, and satyan vs. satun.

Suffix allomorphy does not depend on syntactico-semantic properties either. For the perfect suffix, the correlation with transitivity or agentivity observed is at best a tendency and has many counterexamples (1).

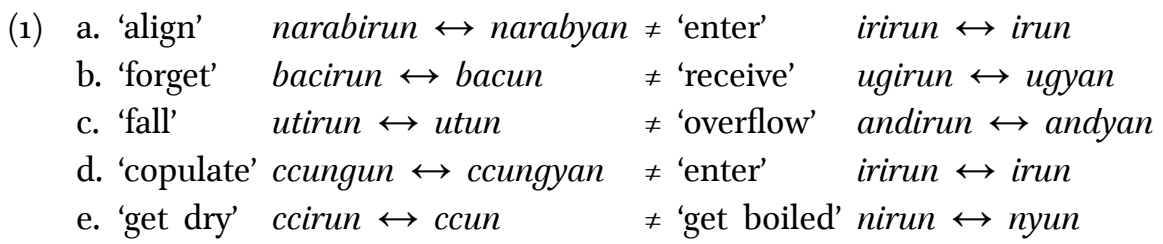

\subsection{Status of suffix allomorphy}

Suffix allomorphy is rather limited in Dunan, and it is thus usually not a good predictor of class membership. The choice of an allomorph is not always predictable from the shape of the stem, and which stem is used with which suffix is anyway idiosyncratic and depends on the conjugation class of a verb. Here again, the analysis needs to recourse to arbitrary co-indexing of stems and suffixes, and since the choice of suffix does not depend on phonological or syntactico-semantic features, it is morphomic.

\section{$5 \quad$ Metatony}

\subsection{Overview of the tone system}

Dunan has a lexical tone system where melodies apply to whole word forms, including any following clitic. Dunan has a three-way opposition between a High $(\mathrm{H})$, Low $(\mathrm{L})$, and Falling $(\mathrm{F})$ word tone. ${ }^{8}$

8 Phonetically, High tone words have a high pitch throughout except for the first syllable of polysyllabic words. Falling tone words are similar to High tone ones, except that they have a falling pitch on the last syllable if it is heavy and they can trigger downstep on a following word. Low tone words have a low pitch throughout. 


\subsection{Analysis of metatony}

Though tones in Dunan are lexically determined, some verbs exhibit tonal alternations within their paradigm (Uwano 2011). Six patterns of paradigmatic metatony can be distinguished, but these can be reduced to four: a single non-alternating class $(\{\mathrm{H}, \mathrm{L}, \mathrm{F}\})$, and three $\mathrm{L} \leftrightarrow \mathrm{F}$ alternating classes (Table 2.8).

TABLE 2.8: Patterns of metatony and their type frequency

\begin{tabular}{|c|c|c|c|c|c|c|}
\hline & $\begin{array}{c}\text { I } \\
\text { hún } \\
\text { 'eat' }\end{array}$ & $\begin{array}{c}\text { II } \\
\text { nàgarirun } \\
\text { 'flow' }\end{array}$ & $\begin{array}{c}\text { III } \\
\text { ndàn } \\
\text { 'get out' }\end{array}$ & $\begin{array}{c}\text { IV } \\
\text { nnùn } \\
\text { 'watch' }\end{array}$ & $\begin{array}{c}\mathrm{V} \\
\text { ùmun } \\
\text { 'think' }\end{array}$ & $\begin{array}{l}\text { VI } \\
\hat{a n n} \\
\text { 'be' }\end{array}$ \\
\hline IMP & \multirow{9}{*}{$\mathrm{H}$} & \multirow{9}{*}{$\mathrm{L}$} & \multirow{7}{*}{$\mathrm{L}$} & \multirow{6}{*}{$\mathrm{L}$} & \multirow{5}{*}{$\mathrm{L}$} & \multirow{9}{*}{$\mathrm{F}$} \\
\hline PROH & & & & & & \\
\hline HORT & & & & & & \\
\hline CIRC & & & & & & \\
\hline PRES & & & & & & \\
\hline PAST & & & & & \multirow{4}{*}{$\mathrm{F}$} & \\
\hline NEG & & & & \multirow{3}{*}{$\mathrm{F}$} & & \\
\hline PERF & & & \multirow{2}{*}{$\mathrm{F}$} & & & \\
\hline MED & & & & & & \\
\hline Freq. & $44.09 \%$ & $14.98 \%$ & $27.09 \%$ & $13.25 \%$ & $0.29 \%$ & $0.29 \%$ \\
\hline
\end{tabular}

Since tones are melodies which apply to whole word forms, they cannot be segmented into a stem part and an affixal part. Moreover, metatonic forms do not always share a common segmental stem form (Table 2.8, 2.9), like the negative (e.g. ûm-anun F) vs. past (e.g. ûmu-tan F) vs. perfect (e.g. ûmw-an F).

Putting the burden of metatony on stems would only lead to increase the number of stems: a new 'hortative' stem would be required, and as a result, only a few forms would share a common stem. Table 2.10 illustrates the increase in the number of stems resulting from attributing metatony to stems. For example, ascribing the $\mathrm{L} \leftrightarrow \mathrm{F}$ alternation to stems leads to double the number of stems posited for a verb like 'tear', whose original stem set $\{$ sag., sat. $\}$ would become \{sàg., sâg., sàt., sât.\}. 
TABLE 2.9: Superposition of stem alternation patterns and metatony

\begin{tabular}{|c|c|c|c|c|c|c|c|c|c|c|c|}
\hline & & $\begin{array}{l}\mathrm{X}=\text { that } \\
\text { 'stand' }\end{array}$ & $\begin{array}{l}\mathrm{X}=\text { sun } \\
\text { 'pull' }\end{array}$ & $\begin{array}{l}\mathrm{X}=n g \\
\text { 'get wet' }\end{array}$ & $\begin{array}{l}\mathrm{X}=\text { hud } \\
\text { 'grow' }\end{array}$ & $\begin{array}{l}\mathrm{X}=k k \\
\text { 'make' }\end{array}$ & $\begin{array}{l}\mathrm{X}=k h \\
\text { 'do' }\end{array}$ & $\begin{array}{l}\mathrm{X}=h \\
\text { 'eat' }\end{array}$ & $\begin{array}{l}\mathrm{X}=d u g \\
\text { 'rest' }\end{array}$ & $\begin{array}{l}\mathrm{X}=\mathrm{mag} \\
\text { 'cook' }\end{array}$ & $\begin{array}{l}\mathrm{X}=u t \quad \mathrm{X}=h \\
\text { 'drop' 'dry' }\end{array}$ \\
\hline & NEG ! & $=$ & X $\mathrm{X} k$ & & & & & $X$ & $\underline{\underline{X}}$ & $\underline{X}$ & $\underline{X} w$ \\
\hline & PRES & $X$ & $\mathrm{Xk}$ & Xar & Xur & Xur & Xir & X & X & $\mathrm{X} a$ & Хu \\
\hline & COND & $\mathrm{X}$ & $\mathrm{X} k$ & Xar & Xur & Xur & Xir & - & - & - & - \\
\hline \multirow[b]{2}{*}{3} & IMP & $\mathrm{X}$ & $\mathrm{X} k$ & Xar & Xur & Xur & Xir & $\mathrm{X} a$ & $\mathrm{Xu}$ & $\mathrm{X} a$ & Хu \\
\hline & CIRC & X & $\mathrm{X} k$ & Xar & Xur & Xur & Xir & $\mathrm{X} a$ & $\mathrm{Xu}$ & $\mathrm{X} a$ & $\mathrm{Xu}$ \\
\hline & PROH & X & $\mathrm{X} k$ & $\mathrm{X} a$ & $\mathrm{Xu}$ & Хu & $\mathrm{X} i$ & X & $\mathrm{X}$ & $\mathrm{X} a$ & Хu \\
\hline & PAST" & & $\bar{x} \bar{t}$ & $\mathrm{X} a$ & $\underline{\underline{X}} \underline{u}$ & $\underline{\mathrm{X}} \bar{u}$ & $\bar{X} i$ & $\underline{\mathrm{X}} \bar{a}$. & $\mathrm{X} u$ & $\bar{X} \bar{a}$ & $\overline{\mathrm{X}} \overline{\underline{u}}$ \\
\hline & HORT & $X$ & $\mathrm{X} t$ & $\mathrm{X} a$ & $\mathrm{Xu}$ & $\mathrm{Xu}$ & $\mathrm{X} i$ & $\mathrm{X} a$ & $\mathrm{Xu}$ & Xas & Xus \\
\hline & MED I & $\bar{X}$ & $\mathrm{X} t$ & $\overline{\mathrm{X}} \bar{a}$ & $\mathrm{X} u$ & $\overline{\mathrm{X}} \bar{u}$ & $\overline{\mathrm{X}} \bar{i}$ & $\mathrm{X} a$ & $\overline{\mathrm{X}} \bar{u}$ & $\mathrm{X} a \mathrm{~s}$ & $\overline{\mathrm{X}} u s$ \\
\hline & PERFi & X & $\mathrm{X} t$ & X & $X$ & $\underline{\mathrm{X}} w$ & X & $X$ & $\mathrm{X} w$ & Xas & Xus \\
\hline
\end{tabular}

TABLE 2.10: Metatony and stems

\begin{tabular}{|c|c|c|c|c|c|c|c|c|}
\hline 'see' & 'tear' & 'raise' & 'rest' & 'teach' & 'dry’ & 'become' & 'make' & ‘slip’ \\
\hline$n n \cdot \mathrm{L}$ & sag. L & kkan. L & $d u g \cdot \mathrm{L}$ & nar. F & $h w \cdot \mathrm{L}$ & $n \cdot \mathrm{F}$ & $k k w \cdot \mathrm{F}$ & ngur. F \\
\hline \multirow[t]{4}{*}{$n n \cdot \mathrm{F}$} & sag. $\mathrm{F}$ & kkan. F & $d u g \cdot \mathrm{F}$ & nara. $\mathrm{L}$ & $h u \cdot \mathrm{L}$ & $n a \cdot \mathrm{L}$ & $k k u \cdot \mathrm{L}$ & nguri. L \\
\hline & sat. $\mathrm{L}$ & kkana. L & dugu. L & naras. I & hus. L & $n a \cdot \mathrm{F}$ & $k k u \cdot \mathrm{F}$ & nguri. $\mathrm{F}$ \\
\hline & sat. F & kkana. F & dugu. F & naras. $\mathrm{F}$ & hus. F & nar. L & kkur. L & ngurir. L \\
\hline & & & $d u g w \cdot \mathrm{F}$ & & & nar. $\mathrm{F}$ & kkur. F & ngurir. $\mathrm{F}$ \\
\hline+1 & +2 & +2 & +2 & +1 & +1 & +2 & +2 & +2 \\
\hline
\end{tabular}

\subsection{Status of metatony}

Like in the case of segmental allomorphy, metatonic forms do not share a common set of syntactic or semantic features. There is indeed no synchronic motivation behind the fact that the perfect and medial forms always undergo metatony in verbs exhibiting alternation, and the generalization that if a verb's past form undergoes metatony then its negative form does too has no motivation (Table 2.8). Metatony cannot therefore be considered to be the exponent of any morphosyntactic feature but has to be analyzed as a morphomic phenomenon. 


\section{$6 \quad$ Opacity}

\subsection{Conjugation classes}

Some conjugation classes in Dunan are barely distinguished from others but differ by a single form only. That form is however not the same one across all classes. This is the case of the negative form, which differs between verbs with otherwise identical paradigms (Table 2.11). For some other classes, it is the perfect that is the only different form (Table 2.12), but the perfect is itself ambiguous regarding class membership, and some verbs crucially lack a perfect form. This makes Dunan's system of conjugation classes an opaque and diffuse system in the sense of Stump \& Finkel (2013).

TABLE 2.11: Opacity in negative forms

\begin{tabular}{lll}
\hline & 'drop' & 'push down' \\
\hline PRESENT & utun $\simeq$ thun \\
IMPERATIVE & utui $\simeq$ thui \\
CIRCUMSTANTIAL & utuiba $\simeq$ thuiba \\
PROHIBITIVE & utunna $\simeq$ thunna \\
PAST & ututan $\simeq$ thutan \\
MEDIAL & utusi $\simeq$ thusi \\
PERFECT & utusyan $\simeq$ thusyan \\
NEGATIVE & utanun $\neq$ thwanun \\
\hline
\end{tabular}

TABLE 2.12: Opacity in perfect forms

\begin{tabular}{lllllll}
\hline & boil' (v.t.) & & 'boil' (v.i.) & 'tear' & & 'bloom' \\
\hline CONDITIONAL & nirya & $=$ & nirya & sagya & $=$ & sagya \\
NEGATIVE & niranun & $=$ & niranun & saganun & $=$ & saganun \\
PRESENT & nirun & $=$ & nirun & sagun & $=$ & sagun \\
CIRCUMSTANTIAL & niruba & $=$ & niruba & saguba & $=$ & saguba \\
PAST & nitan & $=$ & nitan & satitan & $=$ & satitan \\
MEDIAL & nii & $=$ & nii & sati & $=$ & sati \\
PERFECT & nyan & $\neq$ & nyun & satyan & $\neq$ & satun \\
\hline
\end{tabular}




\subsection{Individual forms}

Diagnostic forms determining conjugation class membership are themselves ambiguous when taken in isolation (Figure 2.1). The consequence is that no single form can serve as an optimal principal part, and inferring a full paradigm requires the knowledge of several forms. Due to this opacity, no form can consistently predict another one across all conjugation classes (Table 2.13). ${ }^{9}$ The process of inferring one form from another is thus always confronted with multiple possibilities, 3.5 on the average, but figures can vary greatly. Inferring the perfect from the present is the less reliable (8.04 possibilities), but ambiguity exists even in the best cases, e.g. inferring the present from the circumstantial, 1.13 possibilities on the average.

\subsection{No Blur Principle}

The case of the perfect in Dunan is problematic for the No Blur Principle, which states that "within any set of inflectional affixal realizations for the same paradigmatic cell, no more than one can fail to identify inflection class unambiguously" (Carstairs-McCarthy 1994: 742). Figure 2.2 illustrates that in some cases, all but one of the different possible realizations of the perfect suffix fail to unambiguously predict the present form, and thus the conjugation class of a verb.

NEGATIVE

MEDIAL

PERFECT

NEGATIVE
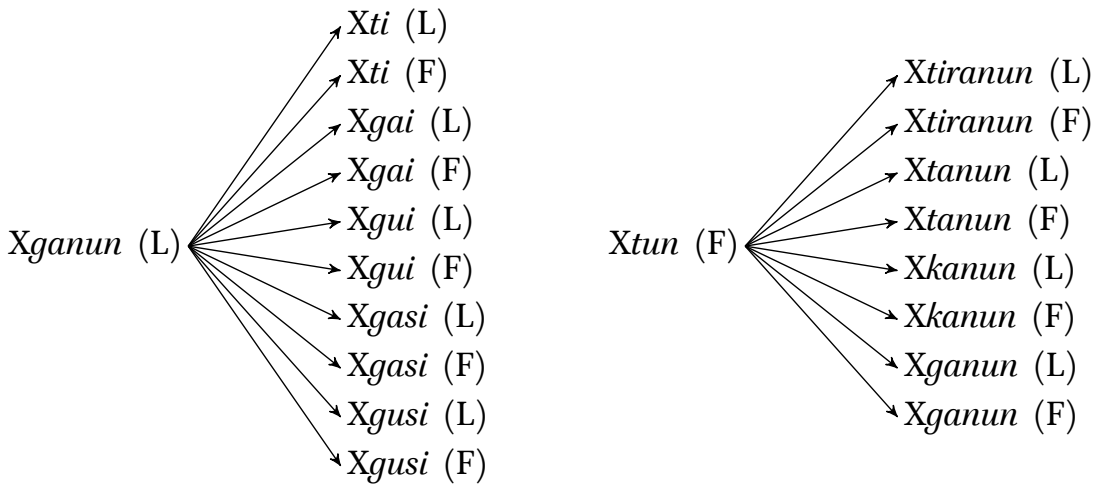

FIGURE 2.1: Ambiguity of diagnostic forms

9 Calculations were done on a set of artificial verbs illustrating all possible combinations of stem alternations, suffix allomorphy and metatony. Table 2.13 thus represents the maximum opacity of the system, without taking into account neither systematic gaps nor frequencies. 
TABLE 2.13: Interpredictability of paradigm cells (e.g. for a given negative form, there are on the average 7.56 different possible corresponding perfect forms)

\begin{tabular}{lllllllllllll}
\hline & \multicolumn{8}{c}{ Predicted (mean number of forms) } \\
\cline { 2 - 12 } Predictor & CIRC & HORT & IMP & MED & NEG & PERF & PRES & PROH & PST & Mean \\
\hline CIRC & & 1.33 & 1.20 & 2.40 & 2.16 & 3.60 & 1.13 & 1.13 & 1.80 & 1.84 \\
HORT & 3.13 & & 3.13 & 1.80 & 6.00 & 5.52 & 2.73 & 2.47 & 3.48 & 3.53 \\
IMP & 1.73 & 1.87 & & 3.36 & 2.04 & 4.56 & 1.13 & 1.67 & 3.12 & 2.44 \\
MED & 5.01 & 1.60 & 5.01 & & 5.33 & 3.07 & 4.37 & 3.95 & 3.09 & 3.93 \\
NEG & 4.01 & 6.53 & 4.01 & 6.53 & & 7.56 & 2.71 & 3.73 & 4.01 & 4.89 \\
PERF & 4.80 & 2.56 & 4.80 & 1.60 & 5.01 & & 4.80 & 4.48 & 2.99 & 3.88 \\
PRES & 2.87 & 3.73 & 2.87 & 6.72 & 3.48 & 8.04 & & 1.73 & 5.16 & 4.33 \\
PROH & 2.67 & 2.47 & 2.93 & 4.44 & 4.20 & 6.84 & 1.73 & & 3.48 & 3.59 \\
PAST & 2.80 & 1.84 & 3.20 & 2.45 & 4.27 & 4.27 & 3.04 & 2.40 & & 3.03 \\
Mean & 3.38 & 2.74 & 3.39 & 3.66 & 4.06 & 5.43 & 2.71 & 2.69 & 3.39 & 3.50 \\
\hline
\end{tabular}

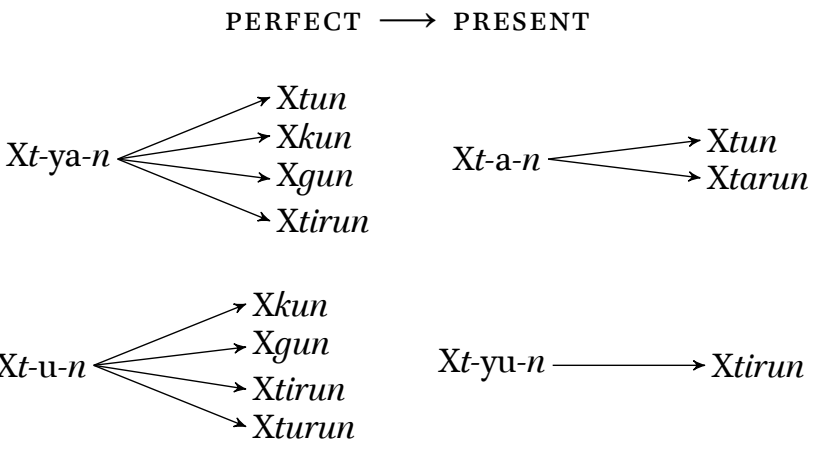

FIGURe 2.2: No Blur Principle

\subsection{Systematic homophony}

Some conjugation classes exhibit syncretism between some of their paradigm cells. This is for example the case for the simple past and perfect past, which are both realized as Xatan for some classes, and also of the medial and imperative forms, both $\mathrm{X} i$ for some verbs.

Etymologically related transitivity pairs also exhibit reciprocal homophony between different cells of their paradigms, like in the case of utun, which can 
realize either the perfect of 'fall' (v.i) or the present of 'drop' (v.t.). Some perfect forms are ambiguously marked with a suffix $-u$, which with a different stem is an exponent of the present, like with 'bloom', present sag-un vs. perfect sat-un.

Such phenomena show that simply listing the presence of a stem or a word form for a verb is insufficient to identify that verb's conjugation class and infer its paradigm. The key information is to know what paradigm cell such a form realizes.

\section{$7 \quad$ Which model?}

\subsection{Morpheme-based morphophonology}

The data presented and analyzed above clearly shows that a morpheme-based morphophonological approach is not apt for describing the verb morphology of Dunan. Such an approach would only lead to posit rules or constraints that are unnatural and lack any generality because of their lexically or morphologically restricted character. Such unmotivated rules would be no more than diachronic changes disguised as synchronic rules.

Such an approach also fails on holistic Gestalt patterns, like 'tear' medial sati, imperative sagi, perfect satyan: $-i$ cannot be an exponent of the medial category since it also marks the imperative, but the velar $\leftrightarrow$ dental alternation cannot be an exponent of the medial either since it also characterizes the hortative, past, and perfect. It is the combination of the two, a specific stem with a specific suffix, that is meaningful.

A morpheme-based approach also generally fails to account for suppletive patterns. No phonological rule can relate 'be' an to its negative form minun. A unified treatment of the morphology, equally able to account for both regular and irregular forms, should be preferred.

\subsection{Root/stem and paradigm}

Several different alternative approaches to classical morpheme-based morphology have been proposed. For example the framework of stem spaces by Montermini \& Bonami (2013) assumes that each lexeme comes equipped with a (possibly redundant) collection of stems indexed to paradigm cells. On the other hand, for Stump \& Finkel (2013), word formation results from the addition of stem realization rules with exponence rules.

However, in the case of Dunan, the ten basic forms require at least eight different stems, and ten stems are needed in order to account for irregular verbs, so that the stem space is more or less equivalent with the basic paradigm. The stem realization rules would also be rather numerous. Plainly listing all the basic forms cannot thus be said to be less economical. 


\subsection{Word and Paradigm}

An abstractive and associative model (Robins 1959, Matthews 1991, Blevins 2006) is particularly attractive in the case of Dunan. It assumes that forms do not exist in isolation but only as part of a structured system of interdependencies and implicational relations. It follows that roots, stems, and affixes are only post hoc abstractions over existing full forms, though they can have a utility as analytical or pedagogical devices. Such a model is thus based on exemplars and principal parts, and it relies on paradigmatic oppositions rather than syntagmatic relations.

In Dunan, there are usually fewer principal parts than stems for a given verb, especially if principal parts are conceived as dynamic sets (Stump \& Finkel 2013), i.e as possibly differing according to the conjugation class. With principal parts, there is no more need to re-encode the information as combination rules and class diacritics, and we can capture implicative generalizations, either unior bidirectional ones, based on actual forms rather than stems:

(2) a. perfect Xyun $\Rightarrow$ circumstantial Xiruba

b. medial Xui $\Longleftrightarrow$ perfect Xwan

\section{Conclusions}

In the verb morphology of Dunan, neither stem alternations, suffix allomorphy, nor metatony can be viewed as clear exponents of syntactic or semantic features. They are thus better analyzed as being morphomic, i.e. purely morphological. Their cross-interactions define several different conjugation classes, which are also morphomic categories. Nevertheless, some secondary cues exist that reinforce the associative network of paradigmatic forms, like the limited correlation with phonotactics and semantics.

Stems and suffixes are not reliable indicators of class membership when taken isolatedly since they require "assembly instructions" (Blevins 2006): in order to know the shape of suffix, one needs to know the shape of the stem, but to know the shape of the stem, one needs to know the conjugation class, and to know the conjugation class, one needs to know the stems and suffixes of a verb. In some cases, like the perfect form, the choice of stem and suffix are even independent.

Dunan's verb morphology is characterized by the abundance of such holistic patterns and by the rather high opacity of its system. The most realistic hypothesis is that speakers memorize whole inflected forms (minimally, principal parts) as part of a network of interdependencies with an implicational 
structure. Unfortunately psycholinguistic tests are hardly feasible in the case of Dunan, a highly endangered language still spoken by elderly persons only. A more computational approach, based on entropy and complexity measures (Ackerman et al. 2009, Finkel \& Stump 2009, Sagot \& Walther 2011, Blevins 2013) is a more realistic goal for future research.

\section{Appendix: Exemplary paradigms}

\begin{tabular}{|c|c|c|c|c|c|c|c|c|c|c|c|}
\hline & $\begin{array}{l}\mathrm{X}=\text { ndam } \\
\text { 'mince' }\end{array}$ & $\begin{array}{l}\mathrm{X}=\text { thabu } \\
\text { 'fold' }\end{array}$ & $\begin{array}{l}\mathrm{X}=b a \\
\text { 'spring' }\end{array}$ & $\begin{array}{l}\mathrm{X}=k k \\
\text { 'use' }\end{array}$ & \multicolumn{2}{|c|}{$\begin{array}{l}\mathrm{X}=p p \\
\text { 'eat' }\end{array}$} & \multicolumn{2}{|l|}{$\begin{array}{l}\mathrm{X}=n n \\
\text { 'kill' }\end{array}$} & \multicolumn{2}{|l|}{$\begin{array}{l}\mathrm{X}=n \\
\text { 'fix' }\end{array}$} & $\begin{array}{l}\mathrm{X}=\text { th } \\
\text { 'drop' }\end{array}$ \\
\hline NEG & Xanun & Xganun & Xganun & Xanun & \multicolumn{2}{|c|}{ Xanun } & \multicolumn{2}{|c|}{ Xanun } & \multicolumn{2}{|l|}{ Xanun } & Xwanun \\
\hline PRES & Xun & Xgun & Xgun & Xun & \multicolumn{2}{|c|}{ Xun } & \multicolumn{2}{|c|}{ Xan } & \multicolumn{2}{|l|}{ Xun } & Xun \\
\hline COND & Xya & Xgya & Xgya & - & \multicolumn{2}{|l|}{-} & \multicolumn{2}{|l|}{-} & \multicolumn{2}{|l|}{-} & - \\
\hline IMP & $\mathrm{X} i$ & $\mathrm{Xgi}$ & $\mathrm{Xgi}$ & $\mathrm{X} a i$ & \multicolumn{2}{|l|}{ Xui } & \multicolumn{2}{|l|}{$\mathrm{X} a i$} & \multicolumn{2}{|l|}{ Xui } & Хui \\
\hline CIRC & Хuba & Xguba & Xguba & Xaiba & \multicolumn{2}{|c|}{ Xuiba } & \multicolumn{2}{|l|}{ Xaiba } & \multicolumn{2}{|l|}{ Xuiba } & Xuiba \\
\hline PROH & Хипna & Xgunna & Xgunna & Xunna & \multicolumn{2}{|c|}{ Хипna } & \multicolumn{2}{|c|}{ Xanna } & \multicolumn{2}{|l|}{ Хипnа } & Xunna \\
\hline PAST & Xitan & Xtitan & Xtitan & Xatan & \multicolumn{2}{|c|}{ Xutan } & \multicolumn{2}{|c|}{ Xatan } & \multicolumn{2}{|l|}{ Xutan } & Xutan \\
\hline HORT & Xindangi & i Xtindangi & Xtindangi $\mathrm{Y}$ & Xaindangi & Xuina & langi & Xasina & dangi & Xusind & langi & Xusindangi \\
\hline MED & $\mathrm{X} i$ & $\mathrm{X} t i$ & Xti $\quad$ I & $\mathrm{X} a i$ & Хui & & $\mathrm{X} a s i$ & & Xusi & & Xusi \\
\hline PERF & Xyan & Xtyan & Xtun & Xan & $\mathrm{X} w a n$ & & Xasyar & & Xusyan & & Xusyan \\
\hline & & $\begin{array}{l}\mathrm{X}=s \\
\text { 'cut' }\end{array}$ & $\begin{array}{l}\mathrm{X}=n t \\
\text { 'sit' }\end{array}$ & $\begin{array}{l}\mathrm{X}=\text { huc } \\
\text { 'grow' }\end{array}$ & & $\begin{array}{l}X= \\
\text { rub }\end{array}$ & & $\begin{array}{l}\mathrm{X}=h \\
\text { 'go' }\end{array}$ & & $\begin{array}{l}\mathrm{X}=n \\
\text { 'die' }\end{array}$ & \\
\hline & NEG & Xaranun & Xuranun & Xurant & & Xira & anun & Xira & anun & Xiral & inun \\
\hline & PRES & Xarun & Xurun & Xurun & & Xiru & & Xiru & & Xirut & \\
\hline & COND & Xarya & Xurya & Xurya & & Xiry & & Xiryc & & Xiryc & \\
\hline & IMP & Xari & Xuri & Xuri & & Xiri & & Xiri & & Xiri & \\
\hline & CIRC & Xaruba & Xuruba & Xurubc & & Xiru & $u b a$ & Xiru & $b a$ & Xiru & \\
\hline & $\mathrm{PROH}$ & Xanna & Xunna & Xunna & & Xin & & Xinn & & Xinn & \\
\hline & PAST & Xatan & Xutan & Xutan & & Xita & & Xital & & Xitar & \\
\hline & HORT & Xaindangi & Xuindang & Xuinda & langi & Xinc & dangi & Xind & dangi & Xind & dangi \\
\hline & MED & $\mathrm{X} a i$ & $\mathrm{Xui}$ & Xui & & $\mathrm{X} i$ & & $\mathrm{X} i$ & & $\mathrm{X} i$ & \\
\hline & PERF & Xan & Xwan & Xun & & Xya & & Xyur & & Xun & \\
\hline
\end{tabular}




\section{References}

Ackerman, Farrell \& Blevins, James P. \& Malouf, Robert. 20o9. Parts and wholes: Implicative patterns in inflectional paradigms. In Blevins, James P. \& Blevins, Juliette (eds.), Analogy in grammar: Form and acquisition, 54-81. Oxford: Oxford University Press.

Arimoto, Mitsuhiko. 2001. Ryūkyū Yonaguni Sonai hōgen no dōshi katsuyōkei no goi on'inron (1). Yasuda Joshi Daigaku Kiyō 29. 1-15.

Aronoff, Mark. 1994. Morphology by itself: Stems and inflectional classes. Cambridge: MIT Press.

Ashworth, David E. 1973. A generative study of the inflectional morphophonemics of the Shuri dialect of Ryukyuan. Ithaca: Cornell University (Doctoral dissertation).

Beesley, Kenneth \& Karttunen, Lauri. 2003. Finite state morphology. Stanford: CSLI Publications.

Blevins, James P. 2006. Word-based morphology. Journal of Linguistics 42(3). $531-573$.

Blevins, James P. 2013. The information-theoretic turn. Psihologija 46(3). 355375 .

Bloch, Bernard. 1946. Studies in Colloquial Japanese I: Inflection. Journal of the American Oriental Society 66(2). 97-109.

Carstairs-McCarthy, Andrew. 1994. Inflection classes, gender, and the principle of contrast. Language $70(4)$. 737-788.

Corbett, Greville G. 2009. Canonical inflectional classes. In Montermini, Fabio \& Boyé, Gilles \& Tseng, Jesse (eds.), Selected proceedings of the 6th décembrettes: Morphology in bordeaux, 1-11. Somerville: Cascadilla Proceedings Project.

Finkel, Raphael \& Stump, Gregory. 20og. Principal parts and degrees of paradigmatic transparency. In Blevins, James P. \& Blevins, Juliette (eds.), Analogy in grammar: Form and acquisition, 13-53. Oxford: Oxford University Press.

Heinrich, Patrick \& Miyara, Shinsho \& Shimoji, Michinori (eds.). 2015. Handbook of the ryukyuan languages: History, structure, and use. Berlin: De Gruyter Mouton.

Ito, Junko \& Mester, Armin. 2004. Morphological contrast and merger: Ranuki in Japanese. Journal of Japanese Linguistics 20. 1-18.

Lawrence, Wayne P. 1990. Nakijin phonology: Feet and extrametricality in a Japanese dialect. Tsukuba: University of Tsukuba (Doctoral dissertation).

Martin, Samuel E. 1952. Morphophonemics of Standard Colloquial Japanese. Baltimore: Linguistic Society of America.

Matthews, Peter H. 1991. Morphology. 2nd edn. Cambridge: Cambridge University Press. 
McCawley, James D. 1968. The phonological component of a grammar of Japanese. The Hague: Mouton.

Montermini, Fabio \& Bonami, Olivier. 2013. Stem spaces and predictability in verbal inflection. Lingue e linguaggio 12(2). 171-19o.

Robins, R. H. 1959. In defence of WP. Transactions of the Philological Society 58(1). 116-144.

Sagot, Benoît \& Walther, Géraldine. 2011. Non-canonical inflection: Data, formalisation and complexity measures. In Mahlow, Cerstin \& Piotrowski, Michael (eds.), Systems and frameworks in computational morphology: Second International Workshop, SFCM 2011, Zurich, Switzerland, August 26, 2011, Proceedings, 23-45. Berlin: Springer.

Shibatani, Masayoshi. 1990. The languages of Japan. Cambridge: Cambridge University Press.

Shimoji, Michinori \& Pellard, Thomas (eds.). 2010. An introduction to Ryukyuan languages. Tokyo: ILCAA.

Stump, Gregory \& Finkel, Raphael. A. 2013. Morphological typology: From word to paradigm. Cambridge: Cambridge University Press.

Uwano, Zendō. 2011. Yonaguni hōgen dōshi katsuyō no akusento shiryō (2). Kokuritsu Kokugo Kenkyūjo Ronshū 2. 135-164.

Yamada, Masahiro \& Pellard, Thomas \& Shimoji, Michinori. 2013. Dunan (Yonaguni)-go no kan'eki bunpō to shizen danwa shiryō. In Takubo, Yukinori (ed.), Ryūkyū rettō no gengo to bunka: Sono kiroku to keishō, 291-324. Tokyo: Kuroshio shuppan.

Yamada, Masahiro \& Pellard, Thomas \& Shimoji, Michinori. 2015. Dunan grammar (Yonaguni Ryukyuan). In Heinrich, Patrick \& Miyara, Shinsho \& Shimoji, Michinori (eds.), Handbook of the ryukyuan languages: History, structure, and use. Handbook of the Ryukyuan languages: History, structure, and use, 449-478. Berlin: De Gruyter Mouton. 